\title{
Probable drug induced systemic lupus erythematosus following prolonged levamisole therapy in a child with frequently relapsing nephrotic syndrome
}

\author{
Manouri P Senanayake ${ }^{1}$, Selvarani Rupasinghe ${ }^{2}$ \\ Sri Lanka Journal of Child Health, 2012; 41(3): 141-142
}

(Key words: drug induced systemic lupus erythematosus; levamisole therapy; child)

Long durations of levamisole therapy are widely used to reduce steroid requirement and relapse rates in children with steroid-dependent frequent-relapsing nephrotic syndrome ${ }^{1,2}$. Levamisole is not a listed cause of drug-induced systemic lupus erythromatosus although lupus-like side effects have been reported ${ }^{3,4}$.

\section{Case Report}

We report a four year old girl who was referred by her family physician for fever, polyarthritis, hair loss, oral ulcers and recurrent chest infections for one year. Her first episode of nephrotic syndrome was at two years. Despite response to prednisolone (modified ISKDC regime), frequent relapses necessitated addition of levamisole $40 \mathrm{mg}$ every other day $(2.5$ $\mathrm{mg} / \mathrm{kg}$ ) and she remained relapse free for twenty months on maintenance therapy. Parents and siblings were healthy with no history of arthritis, autoimmune disease or malignancy.

On examination, she was febrile, pale, had oral ulcers, cervical and axillary lymphadenopathy and localized alopecia. Left ankle and wrist were painful and swollen. There was no jaundice, rashes or bone tenderness. Liver and spleen were $5 \mathrm{~cm}$ and $3 \mathrm{~cm}$ below costal margins. Other systems were normal. Blood pressure was $90 / 60 \mathrm{mmHg}$. Weight and height were at the $10^{\text {th }}$ and $25^{\text {th }}$ centiles,

Investigations showed erythrocyte sedimentation rate was $127 \mathrm{~mm} / 1 \mathrm{st}$ hour, C-reactive protein $30 \mathrm{mg} / \mathrm{dl}$ $(<6 \mathrm{mg} / \mathrm{dl})$, haemoglobin $7.5 \mathrm{~g} / \mathrm{dl}$, white cell count $1,900 / \mathrm{mm}^{3}$, absolute neutrophil count $152 / \mathrm{mm}^{3}$ and platelets $296,000 / \mathrm{mm}^{3}$. Blood picture showed leucopenia, neutropenia, normal platelets and

${ }^{1}$ Professor in Paediatrics, Department of Paediatrics, Faculty of Medicine, University of Colombo, ${ }^{2}$ Registrar in Paediatrics, Lady Ridgeway Hospital for Children, Colombo

(Received on 12 September 2011; Accepted on 28 October 2011) normochromic, normocytic, red cells with no abnormal cells.

Blood and urine cultures were normal. Serum creatinine was $44 \mathrm{mmol} / 1 \quad(27-62)$ and alanine aminotransferase (ALT) 15 IU/1 $(<40)$. Rheumatoid factor was negative, anti nuclear antibody (ANA) titre was $1 / 400$ and anti dsDNA - was negative. Serum complement levels were at the lower range of normal. Serum C3 was $91.5 \mathrm{mg} / \mathrm{dl}(88-250)$ and C4 was $15.4 \mathrm{mg} / \mathrm{dl}(15-75)$.

Chest radiograph showed no mediastinal widening. Liver and spleen had uniform echogenicity on ultrasonic examination and bone marrow showed granulocyte hyperplasia and blast cells $<3 \%$, without infiltration or fibrosis.

Levamisole was discontinued immediately. Although treatment for systemic lupus erythematosus (SLE) was suggested on seeking a second opinion from a special clinic for SLE, we did not give any specific treatment.

Within two weeks of stopping levamisole arthritis and neutropenia resolved spontaneously. Two months later anaemia, alopecia, and hepato-splenomegaly resolved, anti nuclear antibody (ANA) titers became negative and complement levels increased. She has remained well on subsequent follow up for over thirty months.

\section{Discussion}

In this patient, oral ulcers, arthritis, haematological abnormalities and ANA positivity fulfilled the American College of Rheumatology diagnostic criteria for systemic lupus erythematosus although double stranded DNA, antineutrophil cytoplasmic antibodies or antihistone antibodies were not present.

We related levamisole therapy to the diagnosis of SLE because symptoms occurred while on levamisole and disappeared completely after its 
withdrawal. Levamisole is not a recognized cause of drug induced SLE although side effects of autoimmunity have been reported previously ${ }^{5}$. This case report adds to this hypothesis.

\section{References}

1. Mongeau JG, Robitaille PO, Ray F. Clinical efficacy of levamisole in treatment of primary nephrosis in children. Paediatric Nephrology 1988; 2(4): 398-410.

http://dx.doi.org/10.1007/BF00853429

2. British Association for Paediatric Nephrology. Levamisole for corticosteroid-dependent nephrotic syndrome in childhood. Lancet 1991; 337(8757): 1555-7.
3. Levamisole - Concise consumer informationdrugs.com October 2010.

4. Ying G, Ming HZ. Drug induced anti neutrophil cytoplasmic antibody-associated vasculitis. Nephrology 2009; 14(1): 33-41. http://dx.doi.org/10.1111/j.14401797.2009.0110 $\underline{0 . \mathrm{x}}$

5. Barbano G, Ginervi F, Ghiggeri GM, Gusmano $\mathrm{R}$ Disseminated auto immune disease during levamisole treatment of nephrotic syndrome Pediatric Nephrology 1999; 13(7):602-3. http://dx.doi.org/10.1007/s004670050753 